\title{
IMPACT OF COVID 19 ON THE EDUCATION SECTOR
}

\author{
Rajashree Payeng \\ Student-Department of Economics, \\ Gauhati University (Kamrup), India
}

\begin{abstract}
The COVID 19 pandemic has resulted in the disruption of the education sector affecting all the level of education from pre-primary to higher education level. With the increasing number of corona virus cases the state government across the country has locked down transportation, closed all public and private offices including educational institutions. The structure of schooling, learning and teaching methodologies are affected due to the ongoing lockdown, whereby the schools are forced to depend completely on digital platforms like Google classroom, Zoom etc. But the access to technology is limited only to the privileged sections of the society and is limited to only few schools. This paper is an attempt to study the wide disparity amongst the people with respect to access to technology for education during the current scenario and its affect on the teachers and students because of the lack of infrastructure.
\end{abstract}

Key words Corona virus, Education, Technology.

Cite this Article: Rajashree Payeng, Impact of COVID 19 on the Education Sector, International Journal of Management, 11(12), 2020, pp 571-574.

http://iaeme.com/Home/issue/IJM?Volume=11\&Issue=12

\section{INTRODUCTION}

COVID 19 is an infectious respiratory disease caused by a newly discovered corona virus called SARS-COV-2 with a fatality rate between 2-3\%. It has affected over 210 countries of the world and has affected almost 68.3 million of the world population. India alone has over 9 million reported cases. The ongoing pandemic has disrupted the lives of many people of the world and has affected almost all the sectors of the economy including the education sector. With the increase in the number of cases and no immediate solution to stop the disease, countries across the world including India have declared lockdown, travel restriction, closure of schools and colleges, and businesses in order to control the spread of the disease. The current global standstill has shattered the economies of the world as the people are forced to stay at home now. Schools and colleges and other educational institutions have been badly affected as the teaching and learning methodologies were the first to be badly hit by the current lockdown. There is still uncertainty as to when the schools and colleges would reopen. 
Long term closure of educational institution, postponed exams and entrances has created havoc to the lives of the students.

\section{OBJECTIVE}

The main objective of this paper is to look into -

- The wide disparity between the poor and the rich with respect to access to technology for learning.

- Highlight the problem faced by the educational institutions

\section{METHODOLOGY}

This paper is an attempt to study the impact of COVID 19 on the education sector based on primary and secondary data collected from various research paper, newspaper, articles and magazines. Primary sources for this study would be oral narratives collected through observation and personal interviews. The oral sources will be supplemented by literature such as books, journal, articles, etc

\section{BODY}

The world is not the same how it was like a year back. It has dramatically changed over the past year due to the COVID 19 pandemic taking the world by storm. Primarily a health crisis with no known treatment, precaution was the only way known to tackle this novel virus. Hence, governments all over the world were compelled to enforce nationwide lockdown to break the chain of infection. Total lockdown of the country brought with it unprecedented effects on all major sectors of economy and education sector also taking major hit.

India following suit with all major nations announced nationwide lockdown on $23^{\text {rd }}$ March 2020. Since that day all the educational institute in the country remained closed. With no foreseen date for this pandemic to end the government decided to start alternative teaching method through online mode. Various synchronous teaching methods like zoom and asynchronous teaching methods like Google classrooms have been used. But the online teaching mode comes with various challenges. Indian education sector infrastructure was not equipped to cope a pandemic of this magnitude and it does not come as a surprise since India's budget allocation towards higher education is merely $1.3 \%$ of the total budget. Below are some drawbacks of online education:

Lack of psycho social development: Going to school is the best way to raise skills. School time help students develop social awareness and social skills. It also has impact on emotional and competitive spirit in students. The sudden transition from school to behind screen learning will lead to lack of interest and passive learning.

Unprepared teachers: Most of the teachers in India are not trained to teach on online platform and they are not accustomed to the technology available. This leads to low quality of teaching since they are not prepared for this sudden transition. Mischievous students taking advantage of this loophole is of major concern.

Economic disparity among students: One of the major challenges of online education in poor country like India is the economic disparity among students. With many families struggling to meet two times of bread a day it is impossible for them to come up with the required technology to access online resources. News of young students' suicide during COVID 19 pandemic owing to lack of resource is a testament to the above fact. While rural areas also suffer from poor network connectivity to access continuous internet connections. All this leads to inequality in imparting uniform education to all section of the population. 
Stallment of lab and research projects: Although online technology has been one of the main alternative source of learning during this lockdown but teaching of science requires specialized equipped laboratories to impart practical knowledge. Online education fails to do justice in this regard. The pandemic also forced students, researchers unable to continue their research activities due to the lockdown. Many projects require collecting of data, regular surveys, sampling which are stalled with no proper directions.

The closure of educational institute not only interrupts the teaching of students but it also coincides with the key assessment period. Many exams, entrance and interviews have been postponed and cancelled. This is leading to disruption of set academic sessions and waste of valuable student year. The government tried to solve this issue by automatic promotion of students in schools. But cancellation of exam leads to lack of proper evaluation of students and delays the recognition of both high potential and learning difficulties which can have harmful long term consequences. In higher education, some universities and colleges tried to replace traditional exams with online examination. But then lack of technological infrastructure and economical disparity comes into play here again. A student from a poor family and rural background do not have access to required technological infrastructure to attend an online examination. Online examinations also are more likely to have measurement errors than usual and also are more prone to cheating methods by students.

The group of students suffering the most are the - to be graduates. They are losing valuable learning time in their final part of studies. They are also experiencing major interruptions in their final assessment and are currently unsure of their future. They are about to graduate in a period of major economic depression which will lead to lack of job opportunities, unemployment and underemployment. The universities and colleges will also find difficulties to provide placement opportunities. This will have damaging effect on a poor student looking to shoulder the burden of his family once he graduates.

The pandemic also affects the learning of students in professional courses like medical and engineering a great deal. Medical students require clinical classes to acquire and master clinical knowledge. Whereas most of the medical colleges are converted to COVID only hospital and this prevents the learning of clinical knowledge. Final year medical students were also drafted into the fight against COVID in some states. Engineering students on the other hand were deprived of practical and laboratory services.

\section{KEY FINDINGS}

- The pandemic has caused unprecedented challenge for the humanity.

- Affected the structure of school and its teaching and learning methodology.

- There exists a wide economic disparity among the students thus making technology for education affordable for few.

- There is uncertainty over exam cycle due to the long term closure of educational institutions.

- The newly graduates are the most affected because of the pandemic and making them unsure about the future. 


\section{MEASURES TO COPE WITH THE PANDEMIC}

- Increase investment in the education sector in order to build infrastructure to cope with pandemic of this magnitude in the future.

- Increase accessibility of education to all the sections of the population. Inclusive learning solution especially for the low income group by providing infrastructure for online learning in the current scenario of pandemic.

- Remote learning strategies can be adopted in order to take care about the difference in opportunity of the people. Online education mixed with media like radio and television can play a big role.

- Emphasis should also be given to the innovation of new techniques of teaching and learning. For this importance should be given to research and development.

- Parents also has great role to play in such scenario.

- Adapt technology based education even after the lockdown. Teachers should be provided with the required infrastructure for teaching and they should be trained to assist students in their problem beyond the traditional limits of classroom.

\section{CONCLUSION}

Although the lockdown has been relaxed and educational institution are partially open there are still a lot to be desired. Full-fledged classes are still not on. This is the most crucial time for the education sector. Although online education is the most effective method to continue teaching and learning but not everyone can afford technology for online education. Thus the government to seize the opportunity to make education inclusive, effective and resilient than it was before the pandemic and prepare for pandemic of such magnitude in future.

\section{REFERENCES}

[1] Bob Blankerberger and Adam M. William: "COVID and the impact on higher education: The essential role of integrity and accountability" Administration Theoryand Praxis

[2] Daniel John-Education and The COVID 19 Pandemic, UNESCO IBE 2020

[3] Jena kumar Pravat "Impact of Pandemic COVID 19 on Education in India

[4] International Journal of Current Research (IJCR), Vol-12, Issue-7, Page-12582-12586 (2020) DOI- http://journalcra.com/article/impact-pandemic-covid-19-education-india

[5] Kaup Soumya(2020), "Sustaining Academics during Covid 19: The role of online teaching-learning"

[6] Tarkar Preeti (2020) "Impact of COVID19 on Education System". Internationa journal of Advanced Science and Technology

[7] Upoalkpajor Joshua Luther and Upaolkpajor Cornelius Bawa -Asian Journal of Education and Social Studies: "The Impact of COVID 19 on Education in Ghana"

[8] The Impact of COVID 19 on the Higher Education Worldwide Resources for the Higher Educational Institutions. International Association of Universities. 24 April 2020.

[9] Supporting the continuation of teaching and learning during the COVID 19 Pandemic.

[10] Fernande Reimers, Global Education Innovation Initiative, Harvard University

[11] World Health Organisation (2020) WHO Director-General's opening remarks at the media briefing on COVID 19-11 March 2020. Geneva, Switzerland

[12] Key Message and Actions for COVID 19 prevention and control in School UNICEF march 2020. 